\title{
Making and Doing Politics Through Grassroots Scientific Research on the Energy and Petrochemical Industries
}

\author{
SARA WYLIE ${ }^{1}$ \\ NORTHEASTERN UNIVERSITY \\ NiCHOLAS SHAPIRO \\ CHEMicAl HeRITAge Foundation \\ MAX LIBOIRON \\ MEMORIAL UNIVERSITY OF NEWFOUNDLAND
}

\begin{abstract}
The high stakes of emergent environmental crises, from climate change to widespread toxic exposures, have motivated STS practitioners to innovate methodologically, including leveraging STS scholarship to actively remake environmental scientific practice and technologies. This thematic collection brings together current research that transforms how communities and academics identify, study, and collectively respond to contaminants engendered by the fossil fuel and petrochemical industries, including air contamination from hydraulic fracking, marine pollution from petroleum-derived plastics, and hydrocarbon derivatives such as formaldehyde that intoxicate our homes. These interventions make inroads into the "undone science" and "regimes of imperceptibility" of environmental health crises. Authors, most of whom are practitioners, investigate grassroots methods for collaboratively designing and developing lowcost monitoring tools, crowdsourcing data analysis, and imagining ways of redressing toxicity outside of the idioms of science. Collectively, these articles work towards remaking how

${ }^{1}$ Sara Wylie, Email: $\underline{\text { s.wylie@northeastern.edu }}$

Copyright (C) 2017 (Sara Wylie, Nicholas Shapiro, and Max Liboiron). Licensed under the Creative Commons Attribution Non-commercial No Derivatives (by-nc-nd). Available at estsjournal.org.
\end{abstract}


knowledge is made about and across industrial systems by networking community grounded approaches for accounting for environmental health issues created by the fossil fuels and allied petrochemical industries.

\section{Keywords}

engaged STS; making and doing; fracking; hydraulic fracturing; energy; oil and gas; petrochemicals; citizen science; civic science

\section{Introduction}

The question of how STS can actively shape the objects of its critique motivates this thematic collection. We investigate how STS can augment the ability of communities, scientists, and regulatory agencies to understand and evaluate the social and material consequences of industrial infrastructure. Environmental crisis in "late industrialism" (Fortun 2012, 2014) foreground the industrial and environmental impacts of fossil fuel driven, petrochemicaldependent consumer economies. The process of wrestling politically, socially, and scientifically with the twin issues of toxic chemicals and climate change, among other global crises, has made the insufficiency of the regulatory tools and scientific orthodoxies that ushered in our contemporary challenges clear (Boudia \& Jas 2014).

Some scholar-practitioners are leveraging STS scholarship to actively remake scientific practice and technologies to address "undone science" (Frickel et al. 2009), where scientific questions are unanswered or unanswerable by the dominant research paradigms; "regimes of imperceptibility" (Murphy 2006), where scientific monitoring practices make phenomena less, instead of more, perceptible; and to support community autonomy (Wylie et al. 2014; Wylie 2011). This thematic collection highlights these nascent forms of STS work by bringing together current research that investigates the fossil fuel and petrochemical industries from the ground up. The research collected here works to transform how communities can identify, study, and collectively respond to the contaminants the fossil fuel industry engenders, including air contamination from hydraulic fracking, marine pollution from petroleum-derived plastics, and hydrocarbon derivatives such as formaldehyde that intoxicate our homes.

The local instances considered in the articles are connected through a much larger political and technical system, and the stakes of this research are high for communities facing acute and chronic toxic exposure ("fence-line communities" near polluting infrastructure). The industrial oil complex far exceeds the frame of the nation-state (Watts 2005), as it is the 
infrastructural backbone of the contemporary international political system and its shared material economies (Watts 2005; Ferguson 2005; Mitchell 2011; Appel 2015). This globe-spanning industry makes use of and sustains systematic asymmetries between regions of production, consumption, and disposal of fossil fuels for both energy and chemical production. Despite its vast transnational scale, the industry slips from analytic and regulatory grasp by operating in extra-territorial waters (Appel 2011, 2012), by privately securing enclaved properties for production (Ferguson 2005; Bowker 1987, 1994), and by sub-contractual arrangements that make both ownership and culpability hard to pin down (Appel 2012).

As Bowker and Star describe in their work on categories and infrastructure (1999), this complicated, international, but largely invisible infrastructure usually only comes into focus during catastrophic breakdowns such as the BP Gulf oil spill. The explosion of the Deep Water Horizon oil rig in May 2010 brought issues of jurisdiction, culpability, and information access within the industry suddenly to light and made them the subject of protracted public inquiry as efforts to cap the gushing well continued for months. Even then, this singular happening resisted insight into the "whole system" (Beamish 2002; Bond 2011; Frickel and Vincent 2011; Frickel 2008). Moreover, as a major environmental disaster in US, the Deep Water Horizon spill proved insufficient to change or meaningfully restrain extreme fossil fuel infrastructure. As others have shown, the vast machine of fossil fuel extraction is built to resist public accountability and transformation ( $c f$ Edwards 2010; Mitchel 2011; Appel 2011; Wylie 2011, forthcoming).

While liberal empathy and media attention are most easily trained on event-based irruptions of harm that stand out from the ordinary, the products and toxicities of late industrialism are not limited to moments of spectacular failure; "slow disasters" are inescapable even during the normal functioning of industrial infrastructure (Nash 2006; Knowles 2014; Shapiro 2015; Liboiron 2016; Beck 1992; Erikson 1994; Perrow 2011; Nixon 2011; EDAction 2016). Slow disasters are ubiquitous but uneven, as oil industries and their chemicals permeate all aspects of contemporary life, from the production of food and its packaging, to housing and home furnishing materials, to the electricity for lights and gas for cars. While global in their distribution, the effects of industrial toxicants do not impact everyone the same way or to the same degree. What kinds of scholarship and advocacy are required to grasp these vast and uneven systems of intoxication and bring them into a space of oversight?

This thematic collection seeks to integrate grassroots research, environmental science, and STS in ways that connect the oil industry to the places and peoples it impacts, and therein act as a tool for accountability (Offenhuber 2013; Suchman 2016). Authors in this thematic collection offer case studies of three examples of new tools for grassroots environmental health research, 
three case studies of bridging organizations that seek to scale local advocacy to more effectively assess these industries' impacts across communities, as well as two approaches that go beyond science to grasp and imagine alternatives to this system. In the pages that follow, we describe why natural gas and petrochemical infrastructures and their products require new forms of research, and highlight themes shared across the papers in this collection. Second, we look at the importance of bridging organizations to network community research and work to scale their data to respond to this industry across geographic regions. Finally, we caution that "making" should not be embraced without critical analysis, particularly in terms of its relationship to traditional, institutional science. We aim to offer frameworks for how we, as STS scholars, activists, and practitioners, might work with numbers, technology, science, and other ways of knowing our environment without falling into determinist technocracy.

\section{Academic Engagement in Unconventional Oil and Gas Infrastructures}

Unconventional natural gas extraction promised to be the bridge to a "greener" carbon-neutral economy (Roberts 2005; MITEI 2011). In practice, the technologies that enabled unconventional natural gas extraction also dramatically expanded unconventional domestic oil production, leading to historic low prices for both natural gas and oil. In 2014, the US led the world in oil production, outstripping Saudia Arabia and spiking a price war that further drove down oil prices (Smith 2014). The low oil prices are a boon for downstream industries that use oil and gas and potentially slows a shift to renewables (Hartmann and Sam 2016; EIA 2017). In fact, the US Energy Information Administration projects that by 2040 oil and gas will still be the primary sources of energy in the country, accounting for approximately $70 \%$ of energy consumption while renewables would gain only another 5-6\% of the market share (EIA 2017). This prediction could be optimistic, as it assumes a price of $\$ 109$ per barrel of oil while the current price per barrel is closer to $\$ 50$, and the implementation of the Clean Energy Plan, which under the Trump Administration is extremely unlikely (Hartmann and Sam 2016; Mooney 2017).

The low price of natural gas spurred a parallel increase in the production of ethylene, the highest production chemical worldwide (IHS 2011; Breisford 2014). As the feedstock and energy source for making ethylene, natural gas accounts for $70 \%$ of this vital petrochemical's production (IHS 2011). Ethylene is in turn the feedstock for a panoply of synthetic chemicals including polyethylene and polyvinyl chloride (ACC 2017: 21), and its reduced cost supports increased investment throughout the petrochemical sector in forms that range from plastics to paints to personal care products (ACC 2015). Realizing the long-term returns of such an elemental 
industrial product, oil majors such as Shell and Exxon have reinvested in ethylene cracking facilities in the United States for the first time in 20 years (IHS 2011). The development of massive refining capacity in the Marcellus Region threatens to bring with it the host of environmental health threats faced by fenceline communities along the Louisiana Chemical Corridor (Fitzgerald 2012; Allen 2003).

Thus, even while the threats of climate change loom larger and the multi-faceted, interspecies, intergenerational toxicities of plastics and other petrochemicals are illuminated in ever more detail (see Liboiron this thematic collection, as well as Scott 2015; EDAction 2016), financial institutions the world over are investing billions of dollars into profitable fossil fueled futures, from cracking facilities, to their requisite pipelines and liquefied natural gas terminals (see Figure 1). These financial and material investments wed international economic stability to making fossil fuel futures profitable.



Figure 1. Chemical Industry Shale gas investments 2010-2016, Image by American Chemistry Council. ${ }^{2}$

As a result, the production of methane, one of the most potent greenhouse gases (up to 86x that of $\mathrm{CO}_{2}$ in 20 years with climate carbon feedbacks), has spiraled up in the US with the boom in unconventional energy (Myhre 2013). Infrared spectral analysis from satellites and aerial surveys suggests mushrooming concentrations of methane in the US atmosphere, coincident with the spread of gas development (Lyon 2016; Kort 2014). Monitoring of methane production at

2 This image comes from an American Chemistry Council (ACC) Infographic titled “American Chemistry and Energy" available online: https:// web.archive.org/web/20170802140040/https://images.bipac.net/ Files/acc test/img/amchem_and_energy.JPG. For a full reports by the on the influence of shale gas on American chemical manufacturing see AAC (2013/2015/2017). 
wellheads finds "fugitive" methane far above the official estimates offered by regulatory agencies (Frankenberg et al. 2016). Moreover, unconventional energy extraction is a chemically intensive process requiring hundreds of synthetic chemicals, many of which have adverse health effects (Colborn 2011; Webb et al. 2014). Communities living amidst gas extraction are experiencing higher rates of miscarriage, increases in birth defects, and other health effects. These effects can be linked to petrochemicals used in extraction processes called endocrine disruptors, chemicals that derail neurological, immunological, and reproductive development (WHO/UNEP 2013; Mckenzie et al. 2012; Kassotis 2014; Elliot et al. 2016).

Given reciprocal relationships where different facets of the fossil fuel and petrochemical industries demand and produce each other, they should not be considered separate sectors. Rather, they are companion industries that have co-evolved over the $20^{\text {th }}$ century to form a resilient industrial ecology where mutually beneficial dependencies help ensure their future necessity ( $c f$ Haraway 2003). For instance, the infrastructural inertia (Hughes 1987) and largescale investments of cracking facilities will sustain natural gas production well beyond its averred short-term transitional role. At the same time, we lack social and scientific methods as well as regulatory systems capable of tracking these industries across arenas of extraction, transport, processing, and manufacture; across borders and across hazards. As such, the system is notoriously hard to fathom, monitor, regulate, and hold accountable (Edwards 2010; Barry 2006).

How do we evaluate the consequences of this sprawling and heterogeneous infrastructure in terms of human and environmental health? How can the health and ecosystem costs of the industry be made collectively evident? How can those experiencing the costs become connected to create means to systematically study this infrastructure and build social and political leverage to influence these systems? These are political questions as much as material ones.

The way the oil industry developed has acute ramifications for how politics can be done on the ground. The evolution of oil economies and the waning of coal's supremacy through the World Wars reduced European workers' control over and understanding of energy systems (Mitchell 2011). First, coal miner and train worker strikes could not as effectively leverage the chokepoints of the industrial production site control (as the energy supply diversified beyond coal and control over the transit infrastructure as oil travelled by hidden, autonomously operating infrastructure such as pipelines). Thus, worker rights movements lost their primary forms of pressure for forcing systemic change (Mitchell 2011). Secondly, the European working class lost local familiarity with the hazardous experiences of fossil fuel extraction. Oil extraction occurred in distant places with workers who had no claim to citizenship where the oil was 
transported. Instead, European workers became the engineering class that developed technical systems for extracting oil elsewhere (Appel 2011). The lived experience of oil infrastructure is very different from that of coal; while oil extraction may cover a large region, it is organized by individual wells drilled independently by migratory laborers who do not necessarily inhabit the region long-term, as would be the case in a coal-mining community (Mitchell 2011; Bowker 1994). The extracted oil is then transferred by pipeline to ocean liners and then again through buried pipelines. Thus, most people using oil lack an embodied sense of the hazards of producing the fuel for workers, their families, and the environment. Additionally, the rise of oil and decline of coal made energy production an international rather than intra-national process. This shift, along with the increased dependence on oil, bound the fate of nation states to the fate of oil companies and their allied industries (Yergin 1991).

With the re-emergence of significant oil and gas extraction across the US, the US imported forms of resource extraction that were designed to remove as much local oversight and control of production as possible. As Ferguson describes in Seeing like an Oil Company (2005), the less democratic a state, the more its oil extraction can thrive, as less attention needs to be paid to consequences for local inhabitants. Oil infrastructure is often enclaved-physically separating oil infrastructure from the surrounding environment (Bowker 1987, 1994) and protected by private security. Rather than drawing workers from the area, employees are flown in and housed in temporary "man-camps." They work in shifts to maintain a 24-hour operating cycle alien to the 12-hour cycle of most employment activities (Bowker 1994). The offshore oil rig exemplifies this form of technical system as a self-enclosed island working to internalize and privatize the extracted resource that can literally move from location to location (Appel 2012). Such technological zones seem to be technically justified but frequently also do political work, such as reducing local or even national oversight over resource extraction (Barry 2006).

Built as it is through the same technical infrastructure, the experience of US gas and oil patch communities shows that unconventional energy is producing forms of violence similar to those it produces in the "developing" world, including environmental damage that is dismissed as accidental and ignored, as well as boom-bust dynamics that exacerbate inequalities and create sacrifice zones (Willow and Wylie 2014; Lerner 2010). While the modular and mobile infrastructure of fossil fuel extraction enables the industry to move along to other reservoirs following a bust, its social and environmental legacies remain and unfold in place as slow disasters (Nixon 2011). The return to intra-national energy production in "democratic" and overdeveloped nations raises the question: how can communities and researchers, with or without the state, create accountability within fossil fuel extraction infrastructure? What forms of technology, 
research, and governance would help affix this industry to the communities and environments it impacts?

\section{Advocacy and the Academy}

The current unconventional energy boom was made possible by technology development in government laboratories and private universities often funded by large federal investments of public money. Yet academic work with communities is often framed as political work and can be frowned on as a form of advocacy (Allen 2003). For example, researchers receiving funding from the National Institute of Environmental Health to co-develop research with impacted groups such as minority communities experiencing environmental illnesses like asthma have to disclose any presentations they give to government agencies or communities because these activities are classified as "lobbying." Even town hall presentations given by community members working with data gathered by those scientists must be disclosed under lobbying provisions (NIH 2016).

Meanwhile, academic work with and for companies has become an unquestioned norm (Readings 1996). This is particularly true within engineering, where academic collaborations with industry and government investment have been vital to producing unconventional energy by contributing to the development of both hydraulic fracturing and horizontal drilling (Wylie 2015; Shellenberg et al. 2012; Begos 2012). These two technologies made extraction of previously inaccessible oil and gas reserves possible. Wells can now be dug horizontally up to $10 \mathrm{~km}$ through beds of rock that hold oil and gas in their matrix. Hydraulic fracturing involves the underground injection of chemically laced fluids at very high pressures so that rock matrix can be riddled with minute fractures to release hydrocarbons. Through these methods, oil and gas bound up in sandstone, shale, and coal beds can be forced to the surface. These techniques changed the geography of extraction from searching for trapped pockets of oil and gas to exhaustively exploiting huge bands of shale. Shale holds hydrocarbons like a waterlogged sponge where water can be squeezed or sucked from any location (Shellenberg et al. 2012). Virtually any well drilled into a shale formation-like the Marcellus Shale, which runs underneath 5 states—can be forced to produce natural gas (Wilbur 2012). A single well may be fracked anywhere from 3-40 times in its lifecycle; in the United States, wells are fracked an average of 10 times (Montgomery and Smith 2010). Considering that one frack can involve a million gallons of fluid, the waste stream from this industry is vast (Warner et al. 2013; also see Jalbert et al. this thematic collection). The reinjection of this wastewater underground is causing earthquakes (Keranen et al. 2014). 
No engineering college or government agency examined the consequences of this industry holistically during the development of seismic imaging systems, the perfecting of chemical mixes for hydraulic fracking, or experiments in horizontal drilling. For example, no one systematically examined the storage and disposal of the vast quantities of toxic wastewater produced from fracking. Indeed, such questions were rendered unaskable by regulations intended to hasten the gas boom by exempting processes like fracking from provisions of the Safe Drinking Water Act, legislation that protects useable sources of drinking water from underground injection (Wylie 2015). Likewise, no studies were conducted to try to investigate the consequences of unconventional energy for people living atop oil and gas reserves. Families could find themselves suddenly surrounded by oil and gas wells, compressor stations, and gathering pipelines. Small communities' roads and infrastructures were suddenly overcome with traffic. New hazards such as explosive chemical storage facilities moved in beside Walmart and waste ponds filled up and overflowed into yards. What were the effects of these interventions?

These "soft" social science questions that imagine and ground this industry as a lived infrastructure had no purchase during development of these techniques or in the promotional research which extolled "clean" natural gas's promissory future of green secure energy (MITEI 2011; Graves 2012). This lack of purchase is by design. A dangerous chain reaction for reproducing inequity is achieved by framing academic and publicly funded research for and with industries as "value neutral," such as that conducted by MIT's industry-funded Energy Initiative (MITEI 2011; Wylie 2015), while technology development, physical and social scientific work with communities is seen as "advocacy." This research inequity was core to enabling the unconventional energy boom in the first place, by developing unconventional energy without reference to its lived consequences. It continues to be vital to sustaining these forms of extraction by industry and policy demands for an endless cycle of research that has to "prove" readily apparent harms and quantify risks.

We step into this foray from the frontlines, reporting what living amidst this industry is like, working with communities to create "make do" technologies that produce "make do" data, networking between communities and extraction sites, and attempting to imagine an alterative to post hoc measures with better ways of designing and engineering our futures. One premise of this work is that it is important always to try to work at two levels simultaneously-first at the grassroots to capture the physical impacts of this industry and, second, to look beyond the specifics, via networks and scale, to build a systematic view of this infrastructure that includes material, financial, and affective terms. Key to this second task is community organization, an activity that is usually either framed as external to the research process, or fetishized by it (led, of 
course, by academics). Here, we argue that inter- and intra-community organization is central to creating ties between local communities, academic researchers, and governments to build accountability for environmental and human harms that accompany oil and gas infrastructures.

\section{Starting at the Grassroots: From Citizen to Civic Science}

In contexts where there are widespread environmental and health impacts but little information about harms and their causes, communities often turn to collecting, sharing, and leveraging their own data (Corburn 2005; Brown 1997; Ottinger 2010, 2011; Allen 2003). The current term of art for when people without science degrees participate in science is "citizen science." Citizen science has been lauded, sometimes uncritically, as the path to more systematic environmental science and monitoring. The Obama Administration convened an interagency effort to support citizen science led by the national science advisor, John Holdren (Citizen Science 2016; Holdren 2015). Frequently, however, citizen science is not led by citizens. The vast majority of popular citizen science projects engage the public as extra eyes and ears in data collection, such as the longrunning Audubon Christmas bird count and more recent meteorological research projects, where participants provide data on what they observe in their backyards. Another common genre is online projects that ask participants to classify galaxies or identify species from photographs (Timmer 2010). These cases are based on massive, crowd-sourced data processing or observing activities where participants are engaged in science without pay, do not shape the research questions or tools, and the results of data have little impact on socio-technical systems and power relationships, nor on how science is done (Kimura and Kinchy 2016). Most of these projects historically have been targeted toward natural science questions, sometimes to great effect, such as identifying folding structures for proteins that could not be achieved computationally (Mitry et al. 2013; Cooper et al. 2010; Dickinson et al. 2012).

Citizen science is not inherently good (Riesch \& Potter 2014). There are always power asymmetries in citizen science, for example, between legitimized and institutionalized forms of knowledge and lay knowledge, and between citizens and accredited scientists. Moreover, in high stakes situations such as those associated with living and working alongside oil and gas infrastructures, engaging in participatory environmental monitoring that either cannot address the pressing questions of participants about health disparities or cannot be leveraged for state or industry accountability may cause more harm than help. Attempts to find modes of knowledge production that exceed the instrumental scientific logics often turn to speculative, artistic, or affective data practices (e.g. Jeremijenko 2004; Forlano 2014; Rödder 2017). These modes of data 
collection and mobilization play an important role in expanding the imagination of what science and environmental research could be. However, expanding such imaginative horizons while not providing useable data could fail to serve contaminated communities that are desperate for outside help and likely have different wants and needs from technologies compared to what speculative researchers want from those same technologies.

In the contexts we have outlined here, the aims of data production must be developed in dialog with affected communities to attempt to address the complex nexus of lives, livelihoods, and environments. As such, the "citizen science" we cover here is a specific genre of public participation in science premised on the high stakes of living in slow disasters, environmental justice struggles, asymmetrical power relations between oil and gas infrastructures and the state on one hand, and communities and ecosystems on the other.

We describe this form of citizen science as "Civic Science" which, following Fortun and Fortun (2005), is a "science that empowers people to question the state of things rather than simply serving the state" (50; also see Liboiron 2016). We add that such research projects are Civic because they aim to bring the infrastructures responsible for sustaining collective human lives (as presently configured) into a space of public contemplation and accountability. Contrasted to the corporate science animating the current energy boom that aims to privatize resources as commodities, Civic Science aims to raise and answer questions such as: what forms of life and society do infrastructures make more or less possible? What power relationships do they produce between actors animating the system? How are the system experienced by their inhabitants? How can tools of monitoring make concrete changes in living conditions for people who live in and around these infrastructures? Civic Science seeks to understand and respond to the embodied consequences of shared industrial systems by better understanding how those systems are made, what kinds of worlds they make possible, and how those worlds might be otherwise.

STS research has examined how scientists have become involved in supporting communities in these efforts, from training them in scientific terminology and processes, to developing research programs of mutual interest (Allen 2003; Epstein 1995). These "activist" or "community engaged" researchers have helped transform institutional environmental health science into something more community-centered, precautionary, and politically engaged (Minkler 2008; Allen 2003). In addition to helping reformulate how research agendas are set and samples are collected, some scientific researchers have begun engaging in their own form of STS work by analyzing how industry funded studies construct experiments to produce results in their favor (Myers et al. 2009; vom Saal and Hughes 2005). Inspired by such work, this thematic collection showcases how STS researchers are similarly becoming involved in transforming the 
process of environmental health research through engaging in actively redesigning the tools, processes, and sociality of science.

Monitoring technologies and analytical processes play a central role in these efforts. Many STS scholars interested in environmental justice, climate change, and debates over toxicity have investigated how power dynamics are structured in the architectures of present environmental monitoring tools (Murphy 2006; Allen 2003; Brown et al. 2006; Nash 2004/2006; Wylie et. al 2014; Shapiro 2015; Pine \& Liboiron 2015; Dosemagen 2017). For instance, laboratorybased toxicological research depoliticizes and depersonalizes chemical exposure by using genetically standardized model organisms such as rats or a zebra fish and by modeling single chemical exposures in controlled conditions rather than investigating the complexity and heterogeneity of lived human exposures (Murphy 2006; Sellers 1997). While there are wide-scale efforts afoot within organizations like the National Institute of Environmental Health Sciences (NIEHS) to develop multi-chemical screens and more sensitive models for chemical harm (National Toxicology Program 2017), they have yet to shape chemical regulation or chemical engineering significantly. As it stands, nearly 80,000 chemicals on the market have yet to be analyzed for their ability to disrupt hormonal signaling during development (Chemsec n.d.).

Given the ubiquity of industrial chemicals and their infrastructures, epidemiology has a limited ability to track and understand the nuanced differences within individual's histories of exposures and their unique predispositions to harm, both social and biological (Wing 1994). Exposure sciences are still far from diagnostic; we are able to identify hazards only after harm has occurred within a large enough population to achieve statistical significance (Allen 2003/2004). Present environmental monitoring at the federal and state levels tracks a limited range of pollutants in an even more limited number of places (Nash 2004; Jalbert and Matz this thematic collection). These methods of diagnosing environmental hazards have been shaped by the historical practices of chemical and energy industries to influence both science and policy to craft science favorable to their industries, including the shaping regulatory processes and tools (Brandt 2007; Davis FR 2014; Oreskes and Conway 2010; Vogel 2008, 2009, 2012; EDAction 2016). Given these technological and methodological issues, this thematic collection takes up the creation and use of scientific tools and the data they create as central to issues of power, accountability, and change. 


\section{Making Devices and Doing Politics}

We have mentioned how natural gas and citizen science are recently being hailed with an uncritical gusto. So, too, is another term central to our work: "making." On the one hand, teaching consumers to make things that are usually black-boxed may make them less reliant on consumer capitalism and expand the potential to democratize technology development by teaching consumers how devices work (Hatch 2013). On the other hand, a blanket enthusiasm for making only further underlines the cultural lack of understand for the physical hardships already involved in making the fossil fuels, petrochemical and other material systems operate (Sawyer 2004; Saxton 2014; Appel et al. 2015; White 1995). STS can be involved in closing that gap between "making" as an intellectual exercise and "making" as a political and economic act by challenging asymmetric power dynamics of production (Maxigas and Troxler 2014a, 2014b). This includes resisting the romanticizing of back-breaking physical labor, seeing maker and environmental justice citizen scientist movements as two separate movements, and bringing the nitty-gritty of community organizing, academic research, and the maker movement together to study the lived consequences of industrial systems. In this thematic collection, we offer empirical findings, concrete cases, and aspirational gestures of what practicing Civic Science via engaged STS looks like. In what follows we present the papers under three related thematic rubrics: STS in Design, STS in/ of Organizations, and STS Imaginaries.

\section{STS and Design in Disaster Zones}

The first three papers of this thematic collection look at attempts to invent or redesign tools for environmental science, with a focus on how STS researchers can be involved in community-based science efforts in "slow" disaster zones (Knowles 2014) characterized by chronic, invisible, slowmoving environmental harm. The first paper, entitled, "Materializing Exposure: Developing indexical methods for visualizing health hazards related to fossil fuel extraction" by Sara Wylie, Lourdes Vera, Elisabeth Wilder, Deborah Thomas, and Megan McLaughlin explores how traditional STS critiques of black boxes and the scientific preference for visualizations over other forms of knowledge can be used to design sensors for environmental contaminates that better capture exposure experiences. The authors work with communities near oil and gas development to visualize their exposure to hydrogen sulfide $\left(\mathrm{H}_{2} \mathrm{~S}\right)$, a neurotoxic corrosive gas. Their use of photographic paper shows that $\mathrm{H}_{2} \mathrm{~S}$ emissions from the region's oil development are chronic and continuous rather than periodic and accidental, as current regulations assume. This paper 
illustrates one way STS researchers can engage with on-the-ground environmental science by redesigning the tools used in environmental research to indexically map landscapes of exposures.

The second paper by Jacob Matz, Sara Wylie, and Jill Kriesky, entitled, "Participatory Air Monitoring in the Midst of Uncertainty: Residents' Experiences with the Speck Sensor," considers a case of STS researchers working with a community organization in understanding and developing their citizen science efforts. The authors collaborated (and continue to work) with the Environmental Health Project (EHP) in South West Pennsylvania to evaluate a citizen science monitoring effort that uses a low cost particulate monitor, called the Speck, to investigate the air quality impacts of the shale gas boom in the area. The authors worked with EHP to understand how local residents actually use the Speck devices. They explore the critical sophistication of many Speck users who employed the device as an experimental object, as well as evolving their own research programs. Results of their interviews then shaped the next iteration of EHP's research program as they sought to figure out how to provide their community with immediately actionable knowledge of contamination. Responding to concerns that low cost sensors place the burden of monitoring on communities and do not scale up to collective solutions, the authors examine how organizations like EHP are developing forms of civic science that provide immediately useful data real-time to community members and aggregate to offer new scientific findings.

A third paper looks at the long tail of natural gas and oil production through the lens of studying disposal of downstream oil products. "Compromised Agency: The Case of BabyLegs," by Max Liboiron, recounts the story of inventing a low cost device for the study of marine plastic pollution that employs gender norms to subvert the structure of the university patenting system and keep the device in the public domain. The community driving the shape of this technology is the university community participating in the economies of oil, gas, and corporate capitalism with the drive to patent and commodify university research. The case shows how STS critiques of gender roles in science can creatively leverage this system through the design of dismissible "feminine" inventions.

Taken together, these pieces work through the question of how to produce data that is immediately useful to communities and subverts scientific norms, while still "passing" scientific muster. In these projects, some scientific norms are challenged, and some are not, simultaneously, a condition that Liboiron calls "compromised agency," where practices reproduce aspects of the asymmetrical power structures they set out to oppose (also see Shapiro et al., this thematic collection). For example, Liboiron develops monitoring technologies from a feminist perspective, but depends on structural sexism for them to be viable in the field. Likewise, all projects 
discussed in these first three papers create and use tools that appeal to regulatory structures that have failed them. Community tools must be validated by state and industry standards, which risks reinforcing rather than subverting inadequate norms of what counts as data and expanding the scientization of society such that only those with "data" have a voice. In short, these case studies deal with the classic problem of using "the master's tools" to combat the effects of pollution (Lorde 2003).

This is not an avoidable shortcoming, but the character of "making and doing" in disaster zones. Making tools and producing data in contaminated communities is a different genre of intellectual engagement than cultural critique, where "political alignment is manifested through the content of the knowledge produced" (Hale 2006, 98). Rather, as activist research, making tools in disaster zones happens "through a relationship established with [...] people in struggle" and in relation to infrastructures that are already known to cause harm (Hale 2006, 98). As such, Civic Science "requires a substantive transformation in conventional research methods to achieve these goals" (98). Echoing our analysis above, we suggest that a basic methodological ethic for this type of work is that the monitoring technologies and the practices surrounding them have to work. They have to be recognized as reliable. Their results need to be legible to those affected or by those in power so action can be taken, even when ensuring working, reliable, legible technologies and data does not overcome dominant narratives we would prefer to oppose. These are the stakes of making and doing in slow disaster zones.

This is where STS, making practices, and on-the-ground organizing can inform one another: rather than a pure space of critique or playfulness, the cases in this thematic collection are navigating "compromised" situations, generating tensions at the nexus of theory and practice and making both more nuanced. Here, politics-struggles pertaining to power-are characterized by compromise and negotiation at their outset, rather than intellectual productions that are mainly "good to think with." For instance, as we go to publication, there are still questions about the quality of data produced by the Speck Monitors. The latest device by CMU is being evaluated again by the EPA. However, these questions have not prevented their use by communities or their use in peer-review scientific publications. What is the responsibility for STS researchers to question the "facticity" or "uncertainty" of forms of data that are instrumentally useful to for impacted communities? As will be discussed below in another paper Shapiro et al. (this thematic collection) label this issue "the data treadmill" and find this perhaps never ending audit process to be an opportunity for STS researches to pose questions alternative to those imaginable through science. 
Likewise, a serious concern for us is the tension between the abdication of state environmental protections and the individualized burden of data collection (Kinchy et al. 2011). We do not want to continue a trend where non-scientists must do the work of governments and accredited scientists to be healthy. Moreover, the tributary practices of community scientists can also be understood as an expansion in the consumer sensor market, where individuals can purchase electronic sensors, for example, to monitor the air quality of their bike ride to work and seek alternative routes, or to monitor particulate matter at home to know when to turn on an air filter or close a window (Arroyo 2005; Tian et al. 2016; Petersen et al. 2009). These sensors mediate access to clean air, water and soil, for those with the monetary and educational capital to seek them out, interpret their outputs, and act accordingly, but they do not address the conditions for pollution and uneven distribution of wealth and access to monitoring to begin with (cf Steinberg 2010). While sometimes parallel in terms of who is collecting the data and what technology is used, the practices of consumer sensing can run perpendicular to the civic engagement and the collective choreography of the grassroots community science of this issue. How can STS be involved in facilitating an acknowledgement of the very different politics of these two genres of citizen and civic science, and support critical engagement and reshaping of industrial systems? Papers in the thematic collection addresses some of these concerns by highlighting the importance of non-profit civil society organizations like EHP, Fractracker, and SkyTruth for organizing, connecting, and scaling community science efforts.

\section{STS in/of Organizations}

The need to rethink the relationship between the academy and community research is a theme across all papers in this thematic collection. Liboiron's case clearly shows how deeply the corporate science structure works to privatize public interest research, and this requires new tactics on the part of scholars to keep research in the public domain. Likewise, Matz's paper examines the importance of bridging organizations like the Environmental Health Project (EHP) to support, aggregate, and analyze the result of community research. Through such aggregating organizations, there is the possibility of creating new scales of research and monitoring capable of responding to industries as systems. Jalbert and Ottinger, who both offer analysis of new forms of research organization that connect impacted communities and enable crowd analysis of industrial infrastructures, pick up this theme in their respective papers.

In "The Civic Informatics of FracTracker Alliance: Working with Communities to Understand the Unconventional Oil and Gas Industry," Kirk Jalbert, Samantha Malone Rubright, 
and Karen Edelstein look at the emergence of an information-based environmentalist non-profit called FracTracker.org. Originally developed at the University of Pittsburgh, FracTracker's dataadvocacy conflicted with the university's pro-natural gas stance and led the project to spin off into a freestanding non-profit (Jalbert et al., this thematic collection). Working in what might be described as form of critical-experimental geography, FracTracker has helped communities generate and share maps of the impacts of the fracking industry (Thompson 2009). Fracking is uniquely difficult to map. FracTracker worked with impacted communities to address undone research around this industry, which improved different community's abilities to collaborate and advocate around fracking. For example, they mapped New York county level bans on fracking, mapped the proximity of oil train routes to communities, and coordinated a volunteer waterquality network. Their paper reflects the civic science role played by bridging organizations like FracTracker in enabling systematic study of the fossil fuel industry through building collaborations between geographically distributed communities and academics.

In "Crowdsourcing Undone Science," Gwen Ottinger looks at crowdsourcing as a method of addressing undone research about polluting industries. She analyses three cases: SkyTruth, a non-profit, efforts to organize online "crowds" to assess aerial images of shale gas infrastructure; a coke refinery monitoring project by Carnegie Mellon's CREATE lab and a community organization; and her own project organizing crowds to help interpret refinery fenceline monitoring data. She finds that while there is potential for crowdsourcing, grassroots organizations may lack the resources required for such projects. She argues that they are best suited only to certain kinds of undone science similar to those taken up in natural science forms of crowd sourcing, where crowds analyze a large-data set through an already well-defined analytical framework.

Taken together, these papers illustrate that the Civic Scientific work of making evident absences about fossil fuel and petrochemical infrastructures need to be supported by stable organizations that maintain the data, co-ordinate crowdsourced efforts, and network similarly positioned communities across cross-cutting issues. For example, by taking up the methodology of making and mapping databases, FracTracker is able to cut across issues raised by unconventional energy from oil train transit to water pollution to banning fracking. They have become a non-academic institution for critical geography (Thompson 2009; Paglen and Thompson 2006; Paglen 2010). They form an important crossroads where data about the multiple environmental health and social impacts of unconventional extraction can converge. While communities live the material experience of this convergence, Fractracker is becoming a space where data about those experiences can be recognized across communities and groups. Residing 
within this bridging organization, these intersecting archives form a new space for more systematically accounting for the effects of unconventional energy extraction and catalyzing shared methodologies and research questions between geographically distributed frontline line communities and academics (also see Matz et al., this thematic collection). However, could this externalization of state data gathering and mapping functions paradoxically contribute to the neoliberal winnowing of effective governance of industries (cf Kinchy et al. 2011; Kamat 2010)? If so, how can these bridging organizations be meaningfully connected to the state so that they mutually reinforce and sustain each other?

Bridging organizations and agencies have in some cases been actively working toward forming such mutually sustaining relationships. To date, most of these efforts have focused on validating citizen science tools rather than sustaining and networking these important archives. For example, EPA's Office of Innovation opened its laboratories to citizen science tools and is helping to validate emerging instruments such as the Speck (see Matz et al., this thematic collection; EPA 2017). Rhode Island's state Public Health Laboratories similarly organized collaborative field-testing of a citizen science prototype device for formaldehyde monitoring (Gehrke and Shapiro 2015). At the end of the Obama administration, the EPA's Science and Technology Advisory Council wrote a report (with the executive director of Public Lab) that describes the need to integrate citizen science into every aspect of work at the EPA (NACEPT 2016).

In the United States, this opening of collaboration between community-based science and environmental governance abruptly closed with the election of the Donald Trump. The influence of the fossil fuel industry on this administration is readily apparent: five key cabinet positions are held by men who led, invested in, and/or consulted for fossil fuel and pipeline companies. Rex Tillerson-former CEO of Exxon-is now Secretary of State. Scott Pruitt, who as attorney general in Oklahoma coordinated with Devon Energy to sue the EPA, now runs the agency and extolls the need for continued fossil fuel growth despite the apparent market glut (Lipton 2014). This degree of regulatory capture goes beyond merely influencing science, and underlines the present need to imagine and enact alternative imaginaries for both academic work and governance (Orsekes and Conway 2010). The final papers in this thematic collection investigate such imaginaries. 


\section{STS Imaginaries}

An undercurrent in the proceeding papers is the maneuvering required to take on enough of the habitus of capital-S Science to gain legitimacy among credentialed scientists. While the previous papers focused on the complexities of research and advocacy that result from the scientiziation of civic struggles where communities suffering from exposure must have "data" to have a voice, the following papers consider technologies that are gestures towards differently sensed, voiced, and governed worlds. While technologies (from low tech sensors to online platforms for crowdsourcing or distributing data) take center stage in many of the research articles that comprise this collection, we wish not to stress the superiority of these particular tools or approaches. Rather, we highlight what these technologies enable us to differently answer or ask, how different regimes of intellectual property inflect the political potential of technologies, and how technologies can materialize an ethos but should not be ends in themselves.

As Woolgar and Cooper have noted, "technology is good and bad; it is enabling and it is oppressive; it works and it does not; and, as just part of all this, it does and does not have politics" (1999: 443). Following this ambivalence of technology, the articles in this thematic collection collectively lay out methods for materializing critiques of science through alternative practices of science while also noting the political and imaginative shortcomings of relying on scientific ways of knowing to overcome systemic social problems. The paper by Nicholas Shapiro, Nasser Zakariya, and Jody Roberts on methodologies beyond science to invite publics to apprehend their environment, and the piece by Joseph Dumit on playful ways to think through complex systems, offer two approaches to augmenting scientific imaginaries with STS imaginaries. Each situates technology and science in question of what kinds of social worlds they produce.

Shapiro et al.'s paper raises a reflexive critique of community science and synthesizes a broad array of practices to re-route struggles away from the potential pit falls of technocratic reformism. The critique emerges from an ethnographic moment when one of the authors has followed all of the best practices outlined in this thematic collection (utilizing an open-licensed affordable technology, based upon peer review methods, developed through long-term engagement with exposed communities), yet found he was entrenching a restricted set of questions even if he was expanding how questions were asked and who did the asking. Together, the authors posit that Civic Science that focuses exclusively on tool redesign to generate quantitative environmental data can further the scientizing of society and that, just like orthodox 
science, it often gets stuck on a "data treadmill" requiring still further data to make good on its promises that always remain just out of reach.

To foster alternatives to these shortcomings, they assemble a number of engaged STS projects, both their own and numerous others, distilling the affordances of these critical methods for public inquiry and intervention into environmental issues. Shapiro et al. have dubbed this a means of "inviting apprehension," finding affinity for these methods in the multiple meanings of apprehension: perception, cognition, action, and the anxiety of living without the often illusorybut nonetheless reassuring-futures that enumeration and science promise. Such an approach leads them not to a singular approach to monitoring, but to an archipelago of inquiries that do not run away from quantified data collection but create space for other ways of knowing, acting, and problem-setting before science happens.

In line with Shapiro et al.'s gesture to forms of apprehending complex environmental phenomena that exceed science itself, Dumit offers a paper about embracing game design-not as a method of gamifying citizen science (Cooper 2014), but as an analytical method for recognizing the strategies and tactics that sustain and extend sociotechnical infrastructures for unconventional energy extraction. His undergraduate classes designed and built a game around fracking. His piece discusses how games work as a form of critical pedagogy to enable students and researchers to focus on the dynamics that enable this industrial form to resist change and absorb resistance while also producing ecological collapse. Asking students to assume the mindset of corporations pursuing minerals provides them with a new point of view from which to understand the tactics employed by companies to grow and maintain markets. In this game, manipulation of science and information is strategic. The currency of game design and redesign opens up a fruitful space for analyzing how science is made. Investigating this system as a game both enables the students to taken an engineer's perspective rather than experiencing the infrastructure as a given ( $c f$ Stilgoe 1985).

Both Dumit's and Shapiro, Zakariya, and Roberts's pieces ask how can we can widen the work of Civic Science and engaged STS to offer alternative forms of learning about, conceptualizing, and reimagining technical systems so that they might be otherwise. The twin industries of fossil fuels and petrochemicals generate multiple toxicities that demonstrate that the natural and social worlds are inseparable. The social and physical consequences of these industries might be best described through alternative STS imaginaries and infrastructures that account for naturecultures, rather than descriptions provided exclusively by scientific tools that enumerate physical phenomena. 
We propose that Civic Science approaches regard these industries not as primarily economic actors, but as ecological actors, who actively shape the material world through efforts to ensure their own persistence (Jablonka and Lamb 2014). As described above, this industrial ecology is difficult to capture as a system and is structured to elide long-term accountability to the environments and communities it shapes. The papers in this thematic collection account for the physical impacts and products of this industrial system at multiple points in its architecture: at the individual oil wells (Wylie et al. and Ottinger); across raw material transit networks (Jalbert et al.); at refineries where materials are rendered into downstream products (Ottinger); in homes where products are experienced (Matz et al., Shapiro et al.); and after points of disposal (Liboiron). Networked together, these papers offer another life-cycle imaginary for studying the oil, gas, and petrochemical industry as a lived complex system through grassroots research.

Developing research methods and networks that account for oil and gas infrastructures as material systems with interdependent biological, ecological, social, and political properties through hybrid physical and social science inquiry could help better affix this industry to the physical environments and communities it impacts. The goal of these methods and imaginaries is premised on the notion that these industrial enterprises can be transformed in fundamental ways.

\section{Conclusion: An Engaged STS Civic Science}

Across this thematic collection, we consider how emerging practices within STS work to address frontline community needs, create infrastructure for research and monitoring of industrial systems, and simultaneously seek to imagine entirely different systems. In aggregate, the thematic collection offers a kind of family tree of engaged STS work. Authors in the thematic collection are learning how to move across disciplines and sectors. Jalbert, for instance, following his PhD research with FracTracker, was hired by the organization as a manager of community based research. Wylie worked for two years following her PhD to co-found a non-profit, Publiclab.org. Shapiro is now a research fellow with Public Lab, and Liboiron co-organizes international conferences on Open Science Hardware with the group. Matz et al.'s research on EHP's Speck program resulted in both this paper and an internal white paper for the organization. Liboiron was hired as a sociologist, but now directs a feminist marine science laboratory as a physical scientist. These authors are expanding the possibilities of employment and practice in the field of STS and diversifying the kinds of products that can count as STS scholarship. From Dumit's game to Wylie et al.'s photopaper sensors to Liboiron's BabyLegs, scholars are producing material interventions in addition to writing traditional papers. This 
changes what intellectual production looks like and raises such questions for STS about peer review and scholarly recognition that extend beyond papers to material projects. Creating tools requires a material literacy not generally taught as part of STS or social science degree programs. These authors have been acquiring their skills "on the go," building partnerships with engineers and scientists, taking courses, and apprenticing with organizations. This raises the question of how STS programs can develop training in engaged STS research?

These are some of the questions and provocations this thematic collection hopes to leave with STS readers. How can STS increase its purchase in shaping the imaginative terrain of engineering and science? How might we actively build forms of pedagogy, research, and activism that openly aspire to build more responsible and responsive energy and chemical infrastructures? How might these interventions impact powerful structures that support increasing oil and gas extraction even in the face of apparent climate change? We hope the thematic collection itself provides a kind of guidance. It is one approach to the question of how we can build and share our research in ways that look across infrastructures, that query each other's practices, and that require collaboration with others on the ground. We look forward to questions of how to build research collaborations similar to those that companies have long built with engineering universities and so effectively become infrastructural to our own ways of life.

Corporations are failing as a means to manage collective risk, a failure that is supported by the ability of the twin industries of fossil fuels and chemical production to elide their impacts on places and peoples. How might we reconfigure these relationships, or create relationships that can scale to similar effect? Such questions provoke the issue of how to govern and monitor industrial infrastructures and their corporate actors. One possible approach offered in this thematic collection, by Jalbert et al., is to develop disciplinary, grassroots-monitoring techniques for industries, which creates the possibility of system-wide surveillance for corporations that are similar to modernist techniques for disciplining citizens (Foucault 1979). These questions of governance are at the root of this thematic collection. This is what STS has to offer communities, governments, and science: a form of grounded research necessary to robustly ask the question of how we wish to construct our collective futures.

The thematic collection closes with a piece from community organizer and community scientist Deb Thomas. After fifteen years of organizing around oil and gas extraction in her native Wyoming, Thomas describes the chilling impact of a ban on citizen science in the region. In 2013, the Wyoming legislature banned the gathering of environmental resource data-including photographs-on public land if that data was to be submitted to any state or federal agency (Pidot 2015). Thomas' insights are a prescient reminder that the stakes of this game are not just 
environmental and human health, but the fundamental architecture of governance: the right to gather data to lobby state or federal agencies for accountability and change. We conclude with Thomas' voice as a reminder of why academic work is so vital now, and of the many miles yet to travel to create the kind of technoscience capable of responding to the public and environmental health crises of late industrialism.

\section{Author Biography}

Sara Wylie is an Assistant Professor of Sociology/Anthropology and Health Sciences in Northeastern University's Social Science Environmental Health Research Institute. Wylie is a cofounder of Public Lab and EDGI, the Environmental Data and Governance Initiative. Wylie seeks to develop research tools, collaborations and platforms for studying and creating accountability for the fossil fuel and allied petrochemical industries. She has a forthcoming book with Duke University Press on the US boom in unconventional energy production titled: Fractivism

Corporate Bodies and Chemical Bonds.

\section{Author Biography}

Nicholas Shapiro is the Matter, Materials and Culture Fellow at the Chemical Heritage Foundation, the Open Air Fellow at Public Lab, and a Visiting Research Professor at Drexel University.

\section{Author Biography}

Max Liboiron is an Assistant Professor in Geography at Memorial University of Newfoundland and Director of the Civic Laboratory for Environmental Action Research (CLEAR), a feminist, decolonial, marine science laboratory. Liboiron's research bridges the physical and social sciences in its investigation of how marine plastics are represented in science and how these methods of representation relate to action. Liboiron is managing editor of Discard Studies, a member of the Endocrine Disruptors Action Group (EDAction), and a co-organizer for the Gathering for Open Science Hardware (GOSH). 


\section{Acknowledgements}

We would like to thank all of the authors who contributed to this thematic collection and editors at ESTS.

\section{References}

ACC, American Chemistry Council. 2017. The Potential Economic Benefits of an Appalachian Petrochemical Industry. Economics \& Statistics Department. May. https:/ / www.americanchemistry.com/Appalachian-Petrochem-Study /

- 2015. The Rising Competitive Advantage of U.S. Plastics. May. https:// plastics.americanchemistry.com / Education-Resources / Publications / The-RisingCompetitive-Advantage-of-US-Plastics.pdf . 2013. Shale Gas, Competitiveness and New U.S. Chemical Industry Investment: An Analysis Based on Announced Projects. https://www.americanchemistry.com/FirstShale-Study/

Allen, Barbara L. 2003. Uneasy Alchemy Citizens Experts in Louisiana's Chemical Corridor Disputes. Cambridge, MA: MIT Press.

Appel, Hannah. 2011. "Futures: Oil and the Making of Modularity in Equatorial Guinea." PhD diss., Standford University.

. 2012. "Offshore Work: Oil, Modularity, and the How of Capitalism in Equatorial Guinea." American Ethnologist 39(4):692-709.

Mason Arthur, and Michael Watts (eds). 2015. Subterranean Estates, Life Worlds of Oil and Gas. Ithaca NY: Cornell University Press.

Arroyo, Ernesto, Leonardo Bonanni, and Ted Selker. "Waterbot: Exploring Feedback and Persuasive Techniques at the Sink." 2005. In Proceedings of the SIGCHI conference on Human factors in computing systems: 631-639.

Barry, Andrew. 2006. “Technological Zones.” European Journal of Social Theory 9(2):239-253.

Beamish, Thomas D. 2002. Silent Spill: The Organization of an Industrial Crisis. Cambridge, MA: MIT Press.

Beck, Ulrich. Risk society: Towards a New Modernity. Vol. 17. Sage, 1992.

Begos, Kevin. 2012. “Tax Breaks, U.S. Research Play Big Part in Success of Fracking.” Associated Press, September 12. Accessed 31 July 2017. http://www.cleveland.com/nation/ index.ssf / 2012/09/tax_breaks_us_research_play_bi.html 
Bond, D. 2011. "The science of catastrophe: making sense of the BP oil spill." Anthropology NOW, 3(1):36-46.

Boudia, Soraya, and Nathalie Jas, eds. 2014. Powerless Science?: Science and Politics in a Toxic World. Vol. 2. New York City: Berghahn Books.

Bowker, Geoffrey C. 1987. "A Well Ordered Reality: Aspects of the Development of Schlumberger, 1920-39." Social Studies of Science 17(4):611-655. 1994. Science on the Run. Cambridge, MA: MIT Press.

Brandt, Allen. 2007. The Cigarette Century: The Rise Fall and Deadly Persistence of the Product that Defined America. New York: Basic Books.

Brelsford, Robert. 2014. "Rising demand, low-cost feed spur ethylene capacity growth." Oil \& Gas Journal 112(7): 90-98.

Brown, Phil and Edwin Mikkelson. 1997. No Safe Place: Toxic Waste, Leukemia, \& Community Action. Berkeley: University of California Press.

Brown, Phil, Sabrina McCormick, Brian Mayer, Stephen Zavestoski, Rachel Morello-Frosch, Rebecca Gasior Altman, and Laura Senier. 2006. "'A Lab of Our Own': Environmental Causation of Breast Cancer and Challenges to the Dominant Epidemiological Paradigm." Science, Technology, and Human Values 31:499-536.

Chemsec. No date. "Why Hazardous Chemicals." International Chemical Secretariat. Accessed 31 July 2017. Chemsec.org/hazardous-chemicals/.

Citizen Science. 2016. "Welcome to our community." citizenscience.gov homepage Accessed 31 July 2017. https: / / www.citizenscience.gov/community/.

Colborn, Theo, Carol Kwiatowski, Kim Schultz, and Mary Bachran. 2011. "Natural Gas Operations from a Public Health Perspective." Human and Ecological Risk Assessment 17(5): 1039-1056.

Cooper, Seth, Firas Khatib, Adrien Treuille, Janos Barbero, Jeehyung Lee, Michael Beenen, Andrew Leaver-Fay, David Baker, Zoran Popovic, and Foldit players. 2010. "Predicting Protein Structures with a Multiplayer Online Game." Nature 466(7307):756-60.

Corburn, J. 2005. Street Science Community Knowledge and Environmental Health Justice. Cambridge, MA: MIT Press.

Davis, Frederick Rowe. 2014. Banned: a history of pesticides and the science of toxicology. New Haven: Yale University Press.

Dickinson, Janis L, Jennifer Shirk, David Bonter, Rick Bonney, Rhiannon L Crain, Jason Martin, Tina Phillips, and Karen Purcell. 2012. “The Current State of Citizen Science as a Tool for 
Ecological Research and Public Engagement." Frontiers in Ecology and the Environment 10(6):291-97.

Dosemagen, Shannon, Max Liboiron, and Jenny Molloy. 2017. "Gathering for Open Science Hardware 2016." Journal of Open Hardware 1(1).

EDAction. 2016. "Toxic By Design: Eliminating harmful flame retardant chemicals from our bodies, homes, \& communities." Environmental Disruptors Action Group. Accessed 21 July 2017. https: / / endocrinedisruptorsaction.org/2016/10/11/ toxic-by-design/

Edwards, Paul N. 2010. A Vast Machine: Computer Models, Climate Data, and the Politics of Global Warming. Cambridge, MA: MIT Press.

EIA. U.S. Energy Information Association. 2017. “EIA - Annual Energy Outlook 2017.” Accessed 28 July 2017. https://www.eia.gov/outlooks/aeo/.

EPA. 2017. “Air Sensor Toolbox for Citizen Scientists, Researchers and Developers.” United States Environmental Protection Agency. Accessed 28 July 2017. https://www.epa.gov/airsensor-toolbox

Elliott, Elise G., Adrienne S. Ettinger, Brian P. Leaderer, Michael B. Bracken, and Nicole C. Deziel. 2017. "A systematic evaluation of chemicals in hydraulic-fracturing fluids and wastewater for reproductive and developmental toxicity." Journal of Exposure Science and Environmental Epidemiology 27(1): 90-99.

Erikson, K., and William Yule. 1994. "A New Species of Trouble: Explorations in Disaster, Trauma, and Community." Nature 372(6502): 140-140.

Ferguson, James. 2005. "Seeing Like an Oil Company: Space, Security, and Global Capital in Neoliberal Africa." American Anthropologist 107(3):377-382.

Fitzgerald, Sandy. 2012. EPA: Ethylene Cracker Plant Could Cause Major Pollution. Newsmax.com. 27 March 2012. Accessed 31 July 2017. http:/ / www.newsmax.com/US/ pollution-epa-pennsylvania/2012/03/27/id / 433951/.

Forlano, L. and Mathew, A., 2014. "From design fiction to design friction: Speculative and participatory design of values-embedded urban technology." Journal of Urban Technology 21(4):7-24.

Fortun, Kim. 2012. “Ethnography in Late Industrialism.” Cultural Anthropology (27)3:446-64.

—. 2014. "From Latour to late industrialism." HAU: Journal of Ethnographic Theory 4(1): 309-329.

Foucault, Michel. 1977. Discipline and Punish: The Birth of the Prison. Vintage Books.

Frankenberg, Christian, Andrew K. Thorpe, David R. Thompson, Glynn Hulley, Eric Adam Kort, Nick Vance, Jakob Borchardt et al. 2016. "Airborne methane remote measurements reveal 
heavy-tail flux distribution in Four Corners region." Proceedings of the National Academy of Sciences: 201605617.

Frickel, Scott and M. Bess Vincent. 2011. “Katrina's Contamination: Regulatory Knowledge Gaps in the Making and Unmaking of Environmental Contention," In Dynamics of Disaster: Lessons in Risk, Response, and Recovery, edited by Rachel A. Dowty and Barbara L. Allen, 11-28. London: Earthscan.

Frickel, Scott. 2008. “On Missing New Orleans: Lost Knowledge and Knowledge Gaps in an Urban Hazardscape" Environmental History 13(4):634-650.

Gehrke, Gretchen, and Nicholas Shapiro. 2015. “Formaldehyde Measurement: testing Public lab's kit's with DOH's equipment." Public Lab. Accessed 28 July, 2017. https:/ / publiclab.org/ notes / gretchengehrke / 10-07-2015 / formaldehyde-measurement-testing-public-lab-s-kitwith-doh-s-equipment

Gold, Russell, and Tom McGinty. 2013. "Energy Boom Puts Wells in America's Backyards," Wall Street Journal, October 25. Accessed 12 October 2015. http://www.wsj.com/articles/ SB10001424052702303672404579149432365326304

Hale, C. R. 2006. "Activist research v. cultural critique: Indigenous land rights and the contradictions of politically engaged anthropology." Cultural anthropology 21(1):96-120.

Haraway, Donna. 2003. The Companion Species Manifesto: Dogs, People, and Significant Otherness. Chicago: Prickly Paradigm.

Hatch, Mark. The maker movement manifesto: rules for innovation in the new world of crafters, hackers, and tinkerers. McGraw Hill Professional, 2013.

Henderson, J, Liboiron, M. Forthcoming. "Compromise and Action: Tactics for Doing Ethical Research in Disaster Zones" In The New Environmental Crisis: Hazard, Disaster, and the Challenges Ahead, edited by James M. Kendra, Routledge.

Holdren, John. 2015. "Addressing Societal and Scientific Challenges through Citizen Science and Crowdsourcing." Memorandum to the Heads of Executive Departments and Agencies, Executive Office of the President, Office of Science and Technology Policy. Sept $30^{\text {th }}$. Accessed 23 July 2017.

https: / / web.archive.org/web/20170112054246/https:/ / www.whitehouse.gov/ sites/ default/files/microsites/ostp/holdren_citizen_science_memo_092915_0.pdf

Hughes, Thomas P. 1987. "The evolution of large technological systems." The social construction of technological systems: New directions in the sociology and history of technology: 51-82.

IHS. 2011. The Economic and Employment Contributions of Shale Gas in the United States. Prepared for: AMERICA'S NATURAL GAS ALLIANCE. IHS Global Insight (USA) Inc. 
December. Accessed 31 July 2017. http://anga.us/media/content/F7D1750E-9C1EE786-674372E5D5E98A40 / files/ shale-gas-economic-impact-dec-2011.pdf.

Jablonka, Eva, and Marion J. Lamb. 2014. Evolution in Four Dimensions, Revised Edition: Genetic, Epigenetic, Behavioral, and Symbolic Variation in the History of Life. Cambridge, MA: MIT Press.

Jeremijenko, N. and Thacker, E., 2004. Creative Biotechnology: A User's Manual. Locus.

Kamat, Sangeeta. 2004. "The Privatization of Public Interest: Theorizing NGO Discourse in a Neoliberal Era." Review of International Political Economy 11(1):155-76. doi: $10.1080 / 0969229042000179794$.

Kassotis, Christopher D., Donald E. Tillitt, J. Wade Davis, Annette M. Hormann, and Susan C. Nagel. 2014. "Estrogen and Androgen Receptor Activities of Hydraulic Fracturing Chemicals and Surface and Ground Water in a Drilling-Dense Region." Endocrinology 155(3):897-907.

Kimura, Aya H., and Abby Kinchy. 2016. "Citizen Science: Probing the Virtues and Contexts of Participatory Research." Engaging Science, Technology, and Society 2(0):331-61. doi: $10.17351 /$ ests2016.99.

Kinchy, Abby J. and S.L. Perry. 2011. "Can Volunteers Pick up the Slack? Efforts to Fill Knowledge Gaps about the Watershed Effects of Marcellus Shale Gas Development." Duke Environmental Law and Policy Forum 22(2):303-340.

Knowles, S. G. 2014. “Learning from Disaster?: The History of Technology and the Future of Disaster Research." Technology and Culture 55(4):773-784.

Kort EA, et al. 2014. "Four corners: The largest US methane anomaly viewed from space." Geophysical Research Letters 41(19):6898-6903.

Lerner, S., 2010. Sacrifice zones: the front lines of toxic chemical exposure in the United States. Cambridge, MA: MIT Press.

Liboiron, M. 2016. "Redefining pollution and action: The matter of plastics." Journal of Material Culture 21(1):87-110.

Liboiron, M. 2016. “Civic Technologies for Monitoring Marine Plastics." Journal of Ocean Technology 11(2):36-45.

Lipton, Eric. 2014. “Energy Firms in Secretive Alliance With Attorneys General.” The New York Times 6 December. Accessed 31 July 2017. https: / www.nytimes.com/2014/12/07/us/ politics / energy-firms-in-secretive-alliance-with-attorneys-general.html.

Lorde, Audre. 2003."The master's tools will never dismantle the master's house." Feminist postcolonial theory: A reader: 27. 
Lyon, David R., Ramón A. Alvarez, Daniel Zavala-Araiza, Adam R. Brandt, Robert B. Jackson, and Steven P. Hamburg. 2016. "Aerial surveys of elevated hydrocarbon emissions from oil and gas production sites." Environmental science \& technology 50(9):4877-4886.

Maxigas and Troxler, Peter. 2014a. "Fablabs - Spaces for the Deployment of Autonomy?" Journal of Peer Production Issue 5: October. Accessed 23 July 2017. http://peerproduction.net/ issues/issue-5-shared-machine-shops/editorial-section/digitally-operated-atoms-vs-bitsof-rhetoric/.

. eds. 2014b. "Shared Machine Shops." Special issue Journal of Peer Production Issue 5: October.

McKenzie, L., R. Guo, R. Z. Witter, D. A. Savitz, L. S. Newman, et al. 2014. "Birth Outcomes and Maternal Residential Proximity to Natural Gas Development in Rural Colorado." Environmental Health Perspectives 122(4):412-417.

Minkler, Meredith and Nina Wallerstein. 2008. Community-Based Participatory Research for Health: From Process to Outcomes. San Francisco, CA: Jossey-Bass.

Mitchell 2011. Carbon Democracy: Political Power in the Age of Oil. New York: Verso.

MITEI. Massachusetts Institute of Technology Energy Initiative. 2011. "The Future of Natural Gas: An Interdisciplinary MIT Study." http://mitei.mit.edu/publications/reportsstudies / future-natural-gas.

Mitry, Danny, Tunde Peto, Shabina Hayat, James E. Morgan, Kay-Tee Khaw, and Paul J. Foster. 2013. "Crowdsourcing as a novel technique for retinal fundus photography classification: Analysis of Images in the EPIC Norfolk Cohort on behalf of the UKBiobank Eye and Vision Consortium." PloS one 8(8): e71154.

Mooney, Chris. 2017. “Trump Is Targeting the Government's Top Renewable Energy Office for a 69 Percent Budget Cut" The Washington Post. May 23. Accessed 28 July 2017. https:// www.washingtonpost.com/news/energy-environment/wp/2017/05/23/trump-plansa-69-percent-budget-cut-large-staff-reductions-at-clean-energy-office / ? utm_term=.c537978f9a5a.

Montgomery, Carl T. and Michael B. Smith. 2010. “Hydraulic Fracturing: History of an enduring Technology," Journal of Petroleum Technology 62(12):26-40.

Murphy, Michelle. 2006. Sick Building Syndrome and the Problem of Uncertainty: Environmental Politics, Technoscience, and Women Workers. Durham: Duke University Press.

Myers JP, vom Saal FS, Akingbemi BT, Arizono K, Belcher S, Colborn T, Chahoud I, Crain DA, Farabollini F, Guillette LJ Jr, Hassold T, Ho SM, Hunt PA, Iguchi T, Jobling S, Kanno J,Laufer H, Marcus M, McLachlan JA, Nadal A, Oehlmann J, Olea N, Palanza P, 
Parmigiani S, Rubin BS, Schoenfelder G, Sonnenschein C, Soto AM, Talsness CE, Taylor JA, Vandenberg LN, Vandenbergh JG, Vogel S, Watson CS, Welshons WV, Zoeller RT. 2009. "Why Public Health Agencies Cannot Depend on Good Laboratory Practices as a Criterion for Selecting Data: The Case of Bisphenol A." Environmental Health Perspectives 117(3):309-15.

Myhre, Gunnar, Drew Shindell, François-Marie Bréon, William Collins, Jan Fuglestvedt, Jianping Huang, Dorothy Koch et al. 2013. "Anthropogenic and natural radiative forcing." Climate change 423:658-740.

NACEPT (National Advisory Council for Environmental Policy and Technology). 2016. "Environmental Protection belongs to the Public: A Vision for Citizen Science at EPA." December. EPA-219-R-16-001.

Nash, Linda. 2004. “The Fruits of Ill-Health: Pesticides and Workers' Bodies in Post-World War II California." Osiris 19:203-219. . 2006. Inescapable Ecologies: A History of Environment, Disease and Knowledge. Berkeley, CA: University of California.

National Toxicology Program. 2017. Tox21: Toxicology in the 21 ${ }^{\text {st }}$ Century program: https:// ntp.niehs.nih.gov/ results/tox21/index.html

NIH. 2016. "Lobbying Guidance for Grantee Activities." National Institute of Health. Accessed 31 July 2017. http:/ / grants.nih.gov/ policy/lobbying_guidance.htm.

Nixon, R., 2011. Slow Violence and the Environmentalism of the Poor. Cambridge, MA: Harvard University Press.

Oreskes, Naomi and Erik M. Conway. 2010. Merchants of Doubt: How a Handful of Scientists Obscured the Truth on Issues from Tobacco Smoke to Global Warming. New York, NY: Bloomsbury Press.

Ottinger, Gwen. 2010."Buckets of Resistance: Standards and the Effectiveness of Citizen Science." Science, Technology, \& Human Values 35(2):244-270. . and Cohen B (Eds). 2011. Technoscience and Environmental Justice: Expert Cultures in a Grassroots Movement. Cambridge, MA: MIT Press.

Paglen, Trevor. and A. C. Thompson. 2006. Torture taxi: on the trail of the CIA's rendition flights. Brooklyn, NY: Melville House. . 2010. Blank Spots on the Map: The Dark Geography of the Pentagon's Secret World. New York: Penguin.

Perrow, C. 2011. Normal accidents: Living with high risk technologies. Princeton University Press. 
Petersen, D., Steele, J. \& Wilkerson, J. 2009. WattBot: A Residential Electricity Monitoring and Feedback System. in CHI '09 Extended Abstracts on Human Factors in Computing Systems: 2847-2852

Pidot, Justin. 2015. Forbidden Data: Wyoming just criminalized citizen science. Slate. May 11. Accessed 31 July 2017. http: / / www.slate.com/articles/health_and_science/science / 2015/05/

wyoming_law_against_data_collection_protecting_ranchers_by_ignoring_the.html

Pine, Kathleen H., and Max Liboiron. 2015. "The politics of measurement and action." In Proceedings of the 33rd Annual ACM Conference on Human Factors in Computing Systems: 3147-3156.

Readings, Bill. 1996. The University in Ruins. Cambridge, MA: Harvard University Press.

Riesch, H. and Potter, C. 2014. Citizen science as seen by scientists: Methodological, epistemological and ethical dimensions. Public Understanding of Science 23(1):107-120.

Roberts, J. A. 2005. "Creating green chemistry: discursive strategies of a scientific movement." PhD diss., Virginia Polytechnic Institute and State University.

Rödder, Simone. 2017. "The Climate of Science-Art and the Art-Science of the Climate: Meeting Points, Boundary Objects and Boundary Work." Minerva 55(1):93-116.

Sawyer, Suzana. 2004. Crude Chronicles: Indigenous Politics, Multinational Oil and Neoliberalism in Ecuador. Durham, NC: Duke University Press.

Saxton, Dvera. 2014. "Strawberry Fields as Extreme Environments: The Ecobiopolitics of Farmworker Health," Medical Anthropology: Cross-Cultural Studies in Health and Illness 34(2):166-183. DOI: 10.1080/01459740.2014.959167.

Scott, James C. 1998. Seeing Like a State: How Certain Schemes to Improve the Human Condition Have Failed. New Haven, CT: Yale University Press.

Scott, D. N. (Ed.). 2015. Our chemical selves: Gender, toxics, and environmental health. Vancouver: UBC Press.

Shapiro, N. 2015. "Attuning to the chemosphere: Domestic formaldehyde, bodily reasoning, and the chemical sublime." Cultural Anthropology, 30(3):368-393.

Shellenberger, Michael, Ted Nordhaus, Alex Trembath, and Jesse Jenkins. 2012. "Where the Shale Gas Revolution Came From." Breakthrough Institute. May 23. Accessed 31 July 2017. http: / / thebreakthrough.org/index.php/programs / energy-and-climate / where-theshale-gas-revolution-came-from/

Smith, Grant. 2014. “U.S. Overtakes Saudi Arabia as World's Biggest Oil Producer.” Bloomberg News. July 4. 
Steinberg, Ted. 2010. "Can Capitalism Save the Planet?: On the Origins of Green Liberalism." Radical history review (107):7-24.

Stilgoe, John R. 1985. Metropolitan Corridor: Railroads and the American Scene. Yale University Press.

Thompson, Nato (Ed.) 2009. Experimental Geography: radical approaches to landscape, cartography, and urbanism. Brooklyn, NY: Melville House.

Tian, Rundong, Christine Dierk, Christopher Myers, and Eric Paulos. 2016. "MyPart: Personal, Portable, Accurate, Airborne Particle Counting." In Proceedings of the 2016 CHI Conference on Human Factors in Computing Systems: 1338-1348.

Timmer, J. 2010. "Galaxy Zoo shows how well crowdsourced citizen science works.” Ars Technica, Oct. 26. Accessed 31 July 2017 http://arstechnica.com/science/2010/10/galaxy-zooshows-how-well-crowdsourced-citizen-science-works/.

Vogel, Sarah A. 2008. "From 'the Dose Makes the Poison' to 'the Timing Makes the Poison': Conceptualizing Risk in the Synthetic Age." Environmental History 13(4):667-673. . 2009. "The Politics of Plastics: The Making and Unmaking of Bisphenol A 'Safety."”

American Journal of Public Health 99:S559-566.

. 2012. Is It Safe? BPA and the Struggle to Define the Safety of Chemicals. University of California Press Berkley: CA.

Vom Saal, F. S., \& Hughes, C. 2005. "An extensive new literature concerning low-dose effects of bisphenol A shows the need for a new risk assessment." Environmental health perspectives 113(8):926-933.

Watts, Michael. 2005. "Righteous Oil?: Human Rights, the Oil Complex and Corporate Social Responsibility." Annual Review of Environment and Resources 30:373-407.

Webb, Ellen, Sheila Bushkin-Bedient, Amanda Cheng, Christopher D. Kassotis, Victoria Balise, and Susan C. Nagel. 2014. "Developmental and Reproductive Effects of Chemicals Associated with Unconventional Oil and Natural Gas Operations." Reviews on Environmental Health 29(4). doi: 10.1515 / reveh-2014-0057

White, Richard. 1995. “'Are You an Environmentalist or Do You Work for a Living?': Work and Nature" In Uncommon Ground: Rethinking the Human Place in Nature edited by William Cronon. New York: W.W. Norton and Co.

WHO/UNEP. 2013. "State of the Science of Endocrine Disrupting Chemicals - 2012." WHO/ UNEP, 2013. Accessed 31 July 2017. http:/ / www.who.int/ceh/publications/endocrine/ en/.

Wilber, Tom. 2012. Under the Surface: Fracking, Fortunes and the Fate of the Marcellus Shale. Ithaca, NY: Cornell University Press. 
Willow, A. and S.Wylie. 2014. "Politics, ecology and the new anthropology of energy: exploring the emerging frontiers of hydraulic fracking." Journal of Political Ecology 21:222-236.

Wylie, Sara. 2015. "Securing the Natural Gas Boom: The Role of Science, the Academy and Regulatory Capture in the Exemption of Hydraulic Fracturing from Regulatory Oversight." In Subterranean Estates: Life Worlds of Oil and Gas, edited by Hannah Appel, Arthur Mason and Michael Watts. Ithaca, NY: Cornell University Press.

Wylie, Sara, Jalbert K, Dosemagen S, Ratto, M. 2014. “Institutions for Civic Technoscience: How Critical Making is Transforming Environmental Research." The Information Society. 30(2): 116-126.

Yergin, Daniel. 1991. The Prize: The Epic Quest for Oil, Money and Power. New York, NY: Free Press. 